\title{
Teaching NeuroImages: Frontal lobe Streptococcus abscess
}

Teng J. Peng, MD, Justine Cormier, MD, and Sarah F. Wesley, MD, MPH

Neurology ${ }^{\circledR}$ 2019;93:e1032-e1033. doi:10.1212/WNL.0000000000008075

A 21-year-old woman presented with a generalized tonic-clonic seizure, followed by 2 days of worsening headache. She was afebrile with normal serology and normal funduscopic and neurologic examination. CT head showed a frontal mass with surrounding edema concerning for primary brain tumor, demyelination, metastases, or infection. MRI brain revealed a ring-enhancing lesion characteristic for brain abscess. ${ }^{1}$ CSF cultures grew Streptococcus intermedius and the source was presumed to be from dental cleaning 2 weeks prior. ${ }^{2}$ Review of original scans revealed a faint hyperdense ring (figure, B), highlighting this pertinent radiologic finding and importance of considering abscess in patients with frontal lobe lesion, even in the absence of infectious findings.

\section{Author contributions}

T.J. Peng: drafting the manuscript, study concept and design, analysis and interpretation of data, acquisition of data. J. Cormier: revising the manuscript for content, analysis and interpretation of data. S.F. Wesley: revising the manuscript for content, study concept and design, analysis and interpretation of data, study supervision and coordination.

Figure MRI sequence of brain abscess
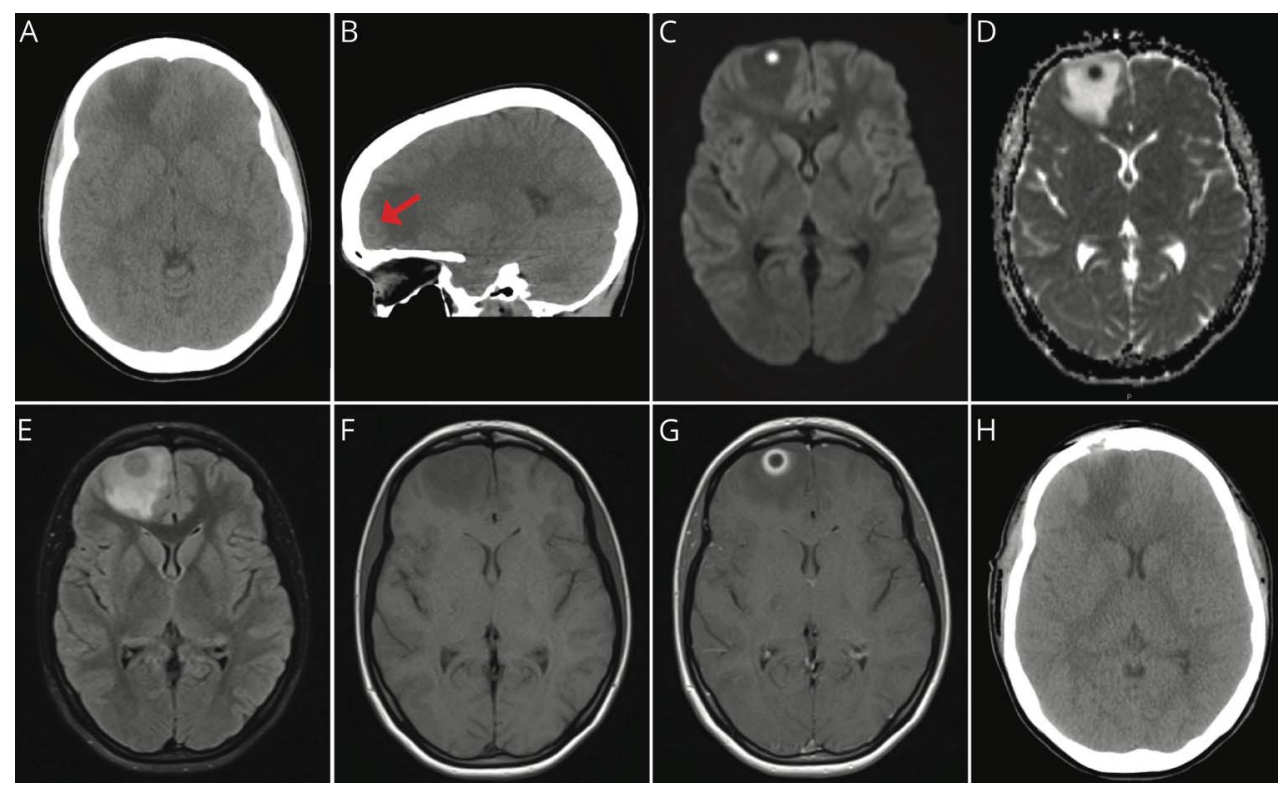

(A) Axial non-contrast-enhanced CT scan of head on admission to hospital shows right frontal mass with surrounding hypodense zone consistent with edema. (B) Sagittal non-contrast-enhanced CT scan with red arrow showing well-circumscribed mass with hyperdense rim and hypodense center surrounded by a large area of hypodense edema. (C) Diffusion-weighted imaging (DWI) shows a hyperintense signal within the abscess. (D) Apparent diffusion coefficient imaging shows an area of hypointensity in the center correlating with hyperintense DWI signal. (E) Fluid-attenuated inversion recovery shows hyperintense area of edema surrounding abscess. (F) T1 precontrast imaging. (G) T1 postgadolinium imaging shows avid ring enhancement. (H) Axial CT scan of patient after craniotomy and washout with diminished abscess.

\section{Correspondence}

Dr. Peng

teng.pengzhao@yale.edu

\section{MORE ONLINE}

\section{$\rightarrow$ Teaching slides}

links.lww.com/WNL/

A949

From the Department of Neurology, Yale University School of Medicine, New Haven, CT.

Go to Neurology.org/N for full disclosures. Funding information and disclosures deemed relevant by the authors, if any, are provided at the end of the article. 


\section{Study funding}

No targeted funding reported.

\section{Disclosure}

T.J. Peng and J. Cormier report no disclosures relevant to the manuscript. S.F. Wesley is a former editorial board member for the Neurology ${ }^{\circledR}$ Resident \& Fellow Section and currently serves as a peer reviewer for Neurology ${ }^{\circledR}$. Go to Neurology. org/ $\mathrm{N}$ for full disclosures.

\section{References}

1. Haimes AB, Zimmerman RD, Morgello S, et al. MR imaging of brain abscesses. AJR Am J Roentgenol 1989;152:1073-1085.

2. Brouwer MC, Tunkel AR, McKhann GM, II, van de Beek D. Brain abscess. N Engl J Med 2014;371:447-456. 


\section{Neurology}

\section{Teaching NeuroImages: Frontal lobe Streptococcus abscess \\ Teng J. Peng, Justine Cormier and Sarah F. Wesley \\ Neurology 2019;93; e1032-e1033 \\ DOI 10.1212/WNL.0000000000008075}

This information is current as of September 2, 2019

Updated Information \& Services

References

Subspecialty Collections

Permissions \& Licensing

Reprints including high resolution figures, can be found at: http://n.neurology.org/content/93/10/e1032.full

This article cites 2 articles, 0 of which you can access for free at: http://n.neurology.org/content/93/10/e1032.full\#ref-list-1

This article, along with others on similar topics, appears in the following collection(s):

Abscess

http://n.neurology.org/cgi/collection/abscess

Bacterial infections

http://n.neurology.org/cgi/collection/bacterial_infections

MRI

http://n.neurology.org/cgi/collection/mri

Secondary headache disorders

http://n.neurology.org/cgi/collection/secondary_headache_disorders

Information about reproducing this article in parts (figures,tables) or in its entirety can be found online at:

http://www.neurology.org/about/about_the_journal\#permissions

Information about ordering reprints can be found online:

http://n.neurology.org/subscribers/advertise

Neurology ${ }^{\circledR}$ is the official journal of the American Academy of Neurology. Published continuously since 1951 , it is now a weekly with 48 issues per year. Copyright @ 2019 American Academy of Neurology. All rights reserved. Print ISSN: 0028-3878. Online ISSN: 1526-632X.

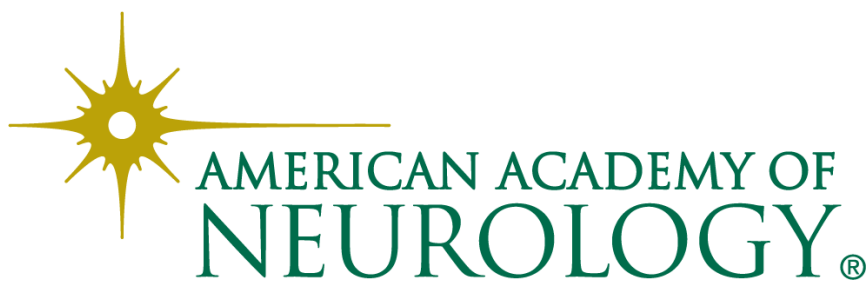

